Braz J Med Biol Res, December 2011, Volume 44(12) 1202-1208

doi: 10.1590/S0100-879X2011007500138

The Streptococcus mutans GlnR protein exhibits an increased affinity for the glnRA operon promoter when bound to $\mathrm{GlnK}$

P. Castellen, F.G.M. Rego, M.E.G. Portugal and E.M. Benelli

The Brazilian Journal of Medical and Biological Research is partially financed by

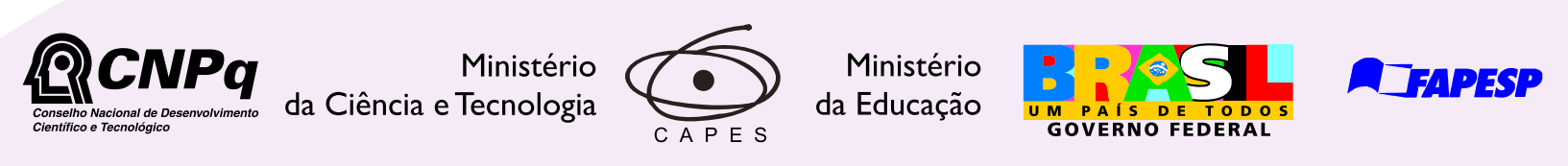

Institutional Sponsors
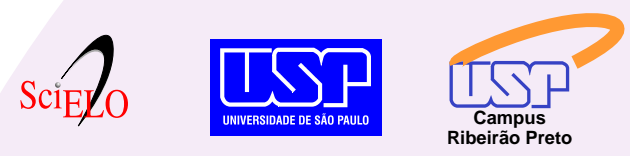

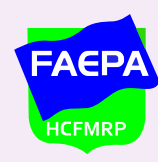

Ф SHIMADZU

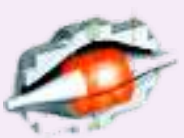

Explore High - Performance MS Orbitrap Technology In Proteomics \& Metabolomics

$\underset{\text { analitica }}{\text { analiticaweb.com.br }}$ SCIENTIFIC 


\title{
The Streptococcus mutans GlnR protein exhibits an increased affinity for the gInRA operon promoter when bound to GInK
}

\author{
P. Castellen ${ }^{1}$, F.G.M. Rego ${ }^{2}$, M.E.G. Portugal ${ }^{1}$ and E.M. Benelli ${ }^{1}$ \\ ${ }^{1}$ Departamento de Bioquímica e Biologia Molecular, ${ }^{2}$ Departamento de Patologia Médica, \\ Universidade Federal do Paraná, Curitiba, PR, Brasil
}

\begin{abstract}
The control of nitrogen metabolism in pathogenic Gram-positive bacteria has been studied in a variety of species and is involved with the expression of virulence factors. To date, no data have been reported regarding nitrogen metabolism in the odontopathogenic species Streptococcus mutans. GInR, which controls nitrogen assimilation in the related bacterial species, Bacillus subtilis, was assessed in S. mutans for its DNA and protein binding activity. Electrophoretic mobility shift assay of the S. mutans GInR protein indicated that GInR binds to promoter regions of the gInRA and amtB-glnK operons. Cross-linking and pull-down assays demonstrated that GInR interacts with $\mathrm{GInK}$, a signal transduction protein that coordinates the regulation of nitrogen metabolism. Upon formation of this stable complex, GInK enhances the affinity of GlnR for the glnRA operon promoter. These results support an involvement of $\mathrm{G} \ln R$ in transcriptional regulation of nitrogen metabolism-related genes and indicate that GInK relays information regarding ammonium availability to GInR.
\end{abstract}

Key words: Streptococcus mutans; GInR; Transcriptional regulator; GInK; PII-type protein

\section{Introduction}

Among odontopathogens, Streptococcus mutans is responsible for most of human dental decay (1). The primary S. mutans virulence factors associated with cariogenicity include adhesion, acidogenicity, and acid tolerance (2). The influence of nitrogen metabolism on virulence has been described for the Gram-positive bacteria $S$. pyogenes, S. pneumoniae, Bacillus anthracis, and Staphylococcus aureus (3-7). A recent study suggested a similar association between putative proteins of nitrogen metabolism and virulence in S. mutans (8).

Most bacteria regulate nitrogen uptake via $A m t B$, a well-conserved ammonium transport membrane protein (9). Intracellularly, nitrogen is assimilated by the glutamine synthetase/glutamate synthetase (GS/GOGAT) pathway or the glutamate dehydrogenase (GDH) pathway (9). The regulation of nitrogen metabolism is coordinated by the PII-type signal transduction proteins, GInB and GInK (formerly NrgB), which control the activities of enzymes, membrane transport proteins, and transcription factors $(9,10)$. Although the GS/GOGAT assimilatory enzymes and PIl signal transduction proteins are widely conserved in
Gram-positive bacteria, other modes of regulating nitrogen metabolism also exist (11).

The regulation of nitrogen metabolism in $S$. mutans is poorly understood. The best characterized Gram-positive bacterium is Bacillus subtilis, which is used as a model organism for low $\mathrm{G}+\mathrm{C}$ Gram-positive bacteria. B. subtilis expresses two DNA-binding proteins of the MerR family, GInR and TnrA, which cooperate in the transcriptional repression or activation of nitrogen metabolism genes $(12,13)$. GInR represses the gInRA and $u r e A B C$ operons, which encode GInR and glutamine synthetase and urea utilization enzymes, respectively, and the tnrA gene (14-16). TnrA activates the transcription of the amtB-glnK (ammonium transport), ure $A B C$, nas $B C$ and nas $D E F$ (nitrate and nitrite utilization) operons and represses glnRA and gltAB, which encodes glutamate synthase (17-20). Feedback-inhibited GS regulates the activities of both proteins by stabilizing the GInR-DNA complex and preventing TnrA from binding to DNA $(21,22)$. A study of the $B$. subtilis GInK protein identified a GInK-TnrA interaction; however, the physiological significance of this interaction remains unknown (23).

Correspondence: E.M. Benelli, Departamento de Bioquímica e Biologia Molecular, Universidade Federal do Paraná, Caixa Postal 19046, 81531-990 Curitiba, PR, Brasil. Fax: +55-41-3266-2042. E-mail: benelli@ufpr.br or el.benelli@yahoo.com.br

Received April 28, 2011. Accepted September 5, 2011. Available online October 21, 2011. Published November 28, 2011. 
Table 1. Bacterial strains and plasmids.

\begin{tabular}{ll}
\hline Strains/plasmids & Genotype/phenotype \\
\hline $\begin{array}{l}\text { Escherichia coli } \\
\text { BL21 Al }\end{array}$ & $\mathrm{F}^{-}$ompT $h s d S_{\mathrm{B}}\left(\mathrm{r}_{\mathrm{B}}^{-} \mathrm{m}_{\mathrm{B}}^{-}\right)$gal dcm araB::T7RNAP-tetA \\
$\begin{array}{l}\text { Streptococcus mutans } \\
\text { UA159 }\end{array}$ & Wild-type strain, Bacteriocin-, BV+, Gramicidin+ (ATCC 700610) \\
$\begin{array}{l}\text { Plasmids } \\
\text { pET28R } \\
\text { pET29R }\end{array}$ & $\mathrm{Km}$ R S. mutans glnR gene cloned into pET28b+, used to express GInR-(His) 6 Present study \\
\hline
\end{tabular}

Studies of nitrogen metabolism in S. mutans may provide insight into the virulence mechanisms of this pathogen. In this report, we demonstrate that $S$. mutans $\mathrm{GInR}$ binds to the promoter regions of $a m t B-g \operatorname{lnK}$ and $g \ln R A$ operons. In addition, we show for the first time a stable interaction between the GInR and GInK proteins. GInK within this complex enhances the affinity of GInR for DNA.

\section{Material and Methods}

\section{Bacterial strains and growth conditions}

Escherichia coli BL21-Al was grown at $37^{\circ} \mathrm{C}$ in Luria broth (LB) or Luria agar (LA) medium supplemented with kanamycin $(50 \mu \mathrm{g} / \mathrm{mL})$ as appropriate (Table 1$)$.

\section{Cloning, expression and purification of recombinant GInR}

The S. mutans UA159 glnR gene was amplified by PCR with primers N-GInR and C-GInR (Table 2) using S. mutans chromosomal DNA as a template. PCR products were digested with $\mathrm{Ndel}$ and $\mathrm{BamHI}$ and cloned into pET28b+ (Novagen, EMD4 Biosciences, USA) to produce the plasmid pET28R, which expresses GInR-(His)6. The same digested PCR products were cloned into pET29b+ (Novagen, EMD4 Biosciences) to produce the plasmid pET29R, which expresses native GInR (Table 1). These plasmids were then transformed into E. coli BL21-Al and transformants were selected on LA supplemented with kanamycin.

Bacteria transformed with pET29R were cultured on $1 \mathrm{~L}$ LB medium at $16^{\circ} \mathrm{C}$ for $16 \mathrm{~h}$ after induction with $0.2 \%$ arabinose. Cells were pelleted by centrifugation, resuspended in buffer $\mathrm{A}(50 \mathrm{mM}$ Tris- $\mathrm{HCl}, \mathrm{pH} 8.0,200 \mathrm{mM} \mathrm{NaCl}, 0.1 \mathrm{mM}$ EDTA, $10 \%$ glycerol), and lysed by sonication. The soluble fraction of the cell extract was purified by ion exchange chromatography on a Q-Sepharose column (GE Healthcare Ltd., UK), and proteins were eluted with an $\mathrm{NaCl}$ gradient (0.2-1 M). Fractions containing GInR were selected after SDS-PAGE visualization. These fractions were mixed and diluted in $50 \mathrm{mM}$ Tris- $\mathrm{HCl}, \mathrm{pH} 8.0$, and $10 \%$ glycerol to a final concentration of $0.2 \mathrm{M} \mathrm{NaCl}$ and loaded onto a heparin column (GE Healthcare Ltd.). Proteins then were eluted through a second $\mathrm{NaCl}$ gradient $(0.2-2 \mathrm{M})$.
Table 2. Primers used in the present study.

\begin{tabular}{ll}
\hline Primer & Sequence \\
\hline N-GInR & 5' GAAAGGAGGAAACATATGAAAG 3' \\
C-GInR & 5' AAAAATTAAGGATCCACGTTACG 3' \\
PamtBfor & 5' AGCTAAGCTTTAGAGCCCTAG 3' \\
PamtBrev & 5' GATAATAAATGCTATAGATCC 3' \\
PglnRfor & 5' GGCCATGAGTAATAAGACGGG 3' \\
PglnRrev & 5' CCGCCATTGATCGTCGAAGC 3' \\
\hline
\end{tabular}

Restriction enzyme cleavage sites are underlined.

GInR fused to an N-terminal hexahistidyl tag was overexpressed in E. coli BL21-Al transformed with pET28R and grown on LA at $30^{\circ} \mathrm{C}$. Cells were harvested by centrifugation, resuspended in lysis buffer $(50 \mathrm{mM}$ Tris- $\mathrm{HCl}$, $\mathrm{pH}$ 8.0, $200 \mathrm{mM} \mathrm{NaCl}, 40 \mathrm{mM}$ imidazole, 10\% glycerol), and disrupted by sonication. The $\mathrm{GInR}-(\mathrm{His})_{6}$ protein was purified from the soluble cell fraction by chromatography on an immobilized nickel ion affinity HisTrap HP column (GE Healthcare Ltd.). Proteins were eluted with an imidazole gradient $(40 \mu \mathrm{M}$ to $1 \mathrm{M})$.

Protein purity was analyzed by $12 \%$ SDS-PAGE (25). Apparently homogeneous fractions were dialyzed in two steps: 1) against the equilibration buffer DA (50 mM Tris$\mathrm{HCl}, \mathrm{pH} 8.0,500 \mathrm{mM} \mathrm{NaCl}, 20 \%$ glycerol), and 2) against the buffer DB (50 mM Tris- $\mathrm{HCl}, \mathrm{pH} 8.0,200 \mathrm{mM} \mathrm{NaCl}$, $20 \%$ glycerol). GInR and GInR-(His)6 proteins were stored in buffer DB, and protein concentration was determined by the Bradford method (26). Protein concentrations were calculated as proteins in monomeric state.

S. mutans GlnK and GlnK-(His)6 proteins were expressed and purified as described by Portugal et al. (27).

\section{Polyclonal antibody production}

Three Wistar albino rats $(140 \pm 20 \mathrm{~g})$ were immunized subcutaneously with $20 \mu \mathrm{g}$ GInR or GInK, both in native form, in complete Freund's adjuvant. Three booster injections were given at 4-week intervals and rats were bled 4 weeks after the last injection. Whole blood was centrifuged 
and the serum was used in the experiments. The antibody specificity was tested in dot blot experiments.

\section{Electrophoretic mobility shift assay (EMSA)}

The S. mutans promoter regions PamtB-glnK and PgInRA were amplified by PCR using primers PamtBforl PamtBrev and PglnRfor/PglnRrev, respectively (Table 2). After amplification, PCR products were purified using the QIAquick PCR Purification Kit (Qiagen, Germany). When indicated, probes were labeled with $\left[\mathrm{Y}^{32} \mathrm{P}\right]-\mathrm{ATP}$ using T4 polynucleotide kinase (New England Biolabs, USA). For DNA binding experiments, reaction buffer (10 mM Tris, $\mathrm{pH} 8.0,5 \mathrm{mM} \mathrm{MgCl}$, $1 \mathrm{mM}$ DTT, 8\% [v/v] glycerol, 0.05\% $N$-octyl glucoside, $100 \mu \mathrm{g} / \mathrm{mL}$ BSA, and $50 \mu \mathrm{g} / \mathrm{mL}$ poly[dA$\mathrm{dC}]$ ) was combined with DNA fragments corresponding to the PgInRA or PamtB-glnK region. Either unlabeled or radiolabeled fragments were used, as indicated. GInR or GInR-(His) 6 was then added at various concentrations, and the reactions were incubated at $30^{\circ} \mathrm{C}$ for $15 \mathrm{~min}$. Samples were subjected to native $6.5 \%$ PAGE in TG buffer $(50 \mathrm{mM}$ Tris, $50 \mathrm{mM}$ glycine, $\mathrm{pH}$ 8.0). Gels were stained with SYBR Green (Invitrogen, USA) when unlabeled DNA fragments were used. Radiolabeled DNA fragments in dried gels were visualized using a Phosphorlmager (Molecular Dynamics, USA) system. Band intensities were analyzed using the LabWorks software (UVP, USA).

The effect of GInK on the binding affinity of GInR to PgInRA DNA was determined by adding various concentrations of native GInK to the incubation buffer.

Approximated apparent dissociation constants $\left(K_{0.5}\right)$ were calculated by fitting the data to a double-reciprocal plot as described by Levitzki (28). $K_{0.5}$ corresponds to the concentration of GInR necessary for $50 \%$ of DNA binding sites to be occupied.

\section{His tag pull-down assays}

GInR/GInK complex formation was studied in vitro using pull-down assays. The proteins $\mathrm{G} \operatorname{lnR}$ and $\mathrm{G} \operatorname{lnK}$ - $(\mathrm{His})_{6}$ were incubated in buffer $\mathrm{A}$ (10-mM Tris, $\mathrm{pH} 8.0,5 \mathrm{mM} \mathrm{MgCl}_{2}, 8 \%$ glycerol, $0.05 \% \mathrm{~N}$-octyl glucoside, $80 \mathrm{mM}$ imidazole) in the presence or absence of $15 \mathrm{nM}$ DNA at room temperature. $\mathrm{Ni}^{2+}$-chelating Sepharose resin $(50 \mu \mathrm{L} ; \mathrm{GE}$ Healthcare Ltd.) was equilibrated in buffer $\mathrm{A}$, and $5 \mu \mathrm{M} \mathrm{GInK}-(\mathrm{His})_{6}$ was added. After $5 \mathrm{~min}, 2.5 \mu \mathrm{M} \mathrm{GlnR}$ was added. The mixtures were washed three times with $300 \mu \mathrm{L}$ buffer A with or without DNA. Proteins were eluted with buffer B $(10 \mathrm{mM}$ Tris, $\mathrm{pH}$ 8.0, $5 \mathrm{mM} \mathrm{MgCl}_{2}, 8 \%$ glycerol, $0.05 \% \mathrm{~N}$-octyl glucoside, 1 $\mathrm{M}$ imidazole). As control, the resin was incubated in buffer A either with GInK-His or GInR proteins. Samples were analyzed by $10 \%$ Tricine-SDS-PAGE stained with colloidal Coomassie blue.

\section{Cross-linking experiments}

The interaction of GlnR and GlnK was further analyzed via chemical cross-linking with glutaraldehyde. GInK and
GInR, both in native form, were incubated in HGNED buffer (1 mM DTT, $100 \mathrm{mM} \mathrm{NaCl}, 0.2 \mathrm{M}$ EDTA, 0.05\% [v/v] NP-40, $10 \%$ glycerol, $25 \mathrm{mM} \mathrm{HEPES}, \mathrm{pH} 8.0$ ) at room temperature for $15 \mathrm{~min}$. Glutaraldehyde was added to a final concentration of $0.1 \%(\mathrm{v} / \mathrm{v})$ and the reactions were quenched after $7 \mathrm{~min}$ by the addition of 0.1 volume of $2 \mathrm{M}$ Tris. Proteins were fractionated by $15 \%$ SDS-PAGE (25) and transferred to polyvinylidene difluoride membranes (Millipore, USA) (29). Membranes were probed with mouse antiserum against GInK or GInR, and proteins were visualized by chemiluminescence using horseradish peroxidase-labeled secondary antibodies and luminol (ECL Western Blotting System, GE Healthcare Ltd.).

In these experiments, the Prestained Protein Molecular Weight Marker (Fermentas, Canada) was used to verify the Western transfer efficiency and to estimate the protein weight through relative mobility (30).

All experiments were performed at least twice.

\section{Results}

\section{GInR binds DNA corresponding to gInK-amtB and gInRA promoters in vitro}

GInR binding to gInK-amt $B$ and $g \ln R A$ promoter regions was examined by EMSA. The $K_{0.5}$ values for PgInRA and PamtB-glnK were 50 and $24 \mathrm{nM}$, respectively (Figure 1Aand $\mathrm{B})$. The PgInRA DNA fragment used in this study includes a putative palindromic binding site (ATGTNAN 7 TNACAT) (8) at $-58 \mathrm{bp}$ relative to the possible transcriptional start point (Figure 1C). The DNA fragment with the PamtB-glnK region contains the putative $\mathrm{GlnR}$ binding site at -18 bp relative to the possible transcriptional start point and $a$ 6 -base conserved repeat at -79 bp (Figure 1C). The presence of two band shifts in GInR concentrations over $50 \mathrm{nM}$ suggests that these binding sites are recognized by $\mathrm{G} \ln R$ in vitro (Figure $1 \mathrm{~B}$ ).

\section{GInR interacts with GInK in vitro}

The oligomeric states of GInR and GInK and complex formation between these proteins were studied using chemical cross-linking with glutaraldehyde (Figure 2A and B). GInR existed as a dimer independently of the presence of gInRA promoter DNA (Figure 2A, lanes 2 and 3). After chemical cross-linking, GInK protein samples were visualized as five bands with different migration characteristics (Figure 2B, lane 5). Although this result may be explained as a cross-linking artifact, it is also possible that GInK exists as five different oligomers under the tested conditions. The observed bands possibly correspond to many oligomeric forms of GInK. GInR interacts directly with different putative GInK oligomers (Figure 2A, lane 7).

Complex formation between native GInR and GInK(His)6 was examined using pull-down assays in the absence or presence of gInRA promoter DNA (Figure 2C and D). GInR was found to stably interact with $G \operatorname{lnK}$ in the absence 

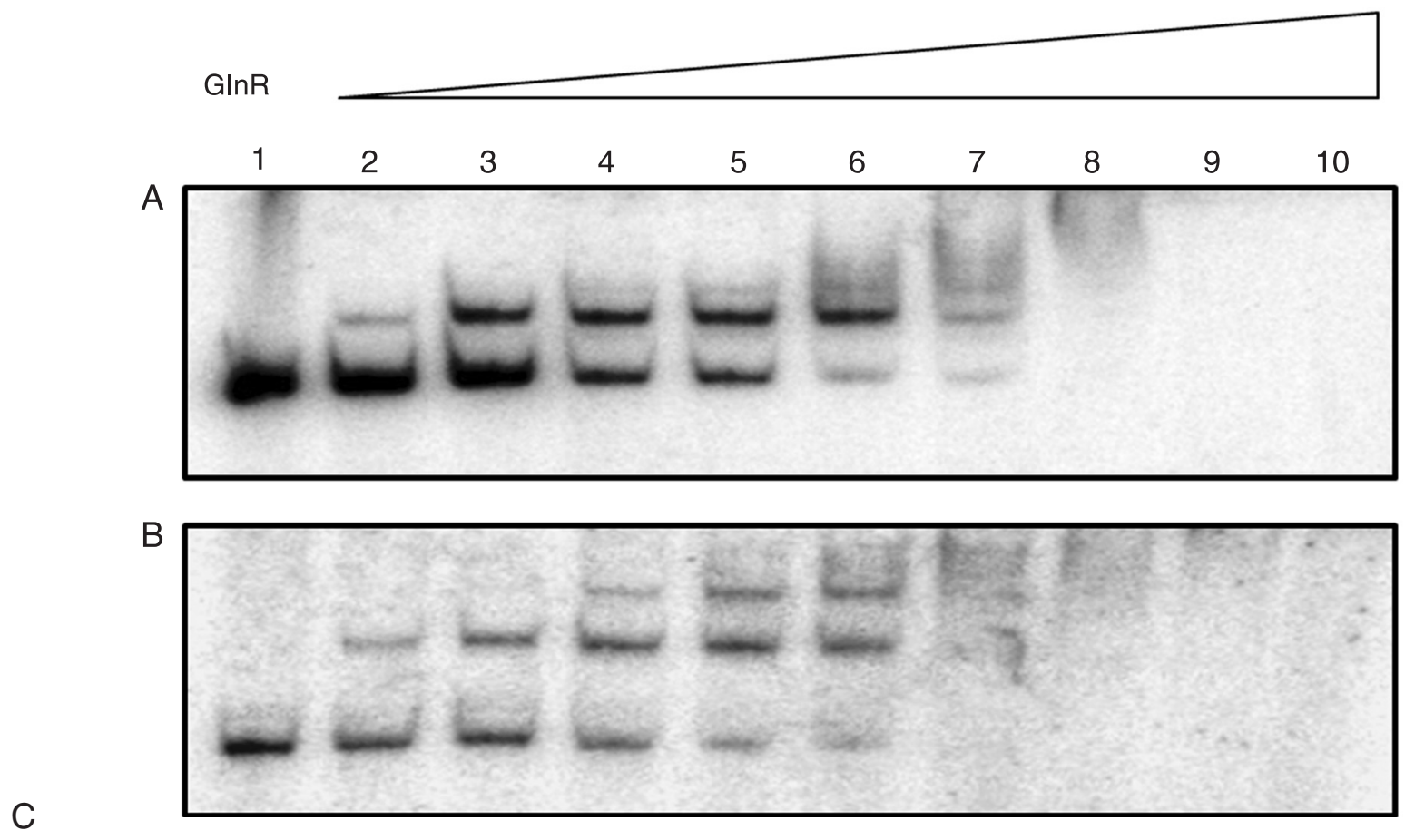

PamtBglnK

-133 AAGCTTTAGA GCCCTAGTAC TATAATATTT TCAAATAATA TAAdATGTTA TATTCTCTGA
-63 ATTTTTAGAA AATTTCGCCA AAAAATCTTT TATTTTCCTG AAAATATGTT ATATTATATA
-3 ACATAAAGGG AGGTGCTGAT AGATATGGAT TCAGGATCTA TAGCATTTAT TATC
$*$ $\operatorname{PgInRA}$

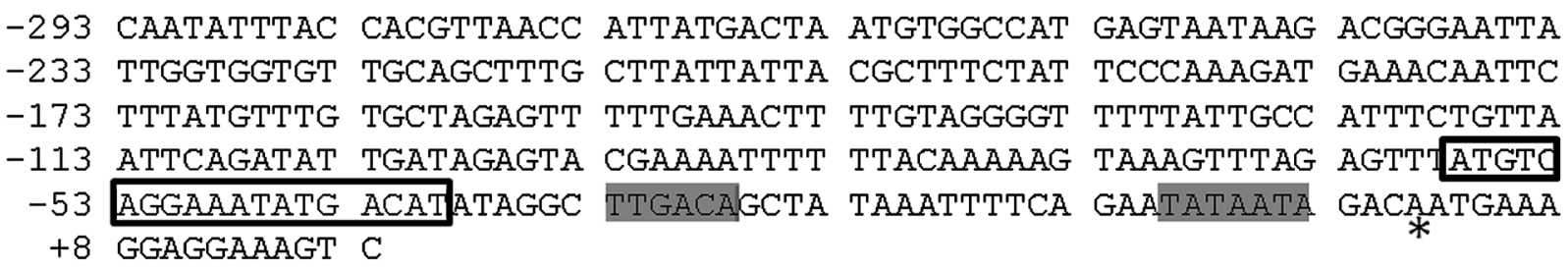
D ATGTNANNNNNNNTNACAT

Figure 1. GlnR-(His) $)_{6}$ binding to DNA. $A$, Increasing quantities of $\mathrm{GlnR}$-(His) 6 were incubated in the presence of $0.3 \mathrm{nM}$ of a radiolabeled $g \ln R A$ promoter DNA fragment (311 bp). Lane $1=$ no $\mathrm{GlnR}$; lanes 2-10 =10, 25, 50, 10, 250, and $500 \mathrm{nM}, 1,2.5$, and $5 \mu \mathrm{M}$ $\mathrm{GlnR}$, respectively. $B$, Increasing quantities of $\mathrm{G} \operatorname{lnR}$-(His) $)_{6}$ were incubated in the presence of $0.6 \mathrm{nM}$ of an amtB-glnK promoter DNA fragment (174 bp). Lane $1=$ no GlnR; lanes $2-10=10,25,50,10,250$, and $500 \mathrm{nM}, 1,2.5$, and $5 \mu \mathrm{M}$ GInR, respectively. C, DNA sequence of amtB-gInK and $g I n R A$ promoter regions. The putative GInR binding sites (8) are boxed, the possible transcription start points are indicated by asterisks and possible -10 and -35 elements are presented in gray boxes. These are the sequences of DNA fragments used in electrophoretic mobility shift assay (EMSA) experiments. $D$, GInR binding site consensus sequence with 6 -base inverted repeats spaced by $7 \mathrm{nt}(8)$. 
of DNA or in the presence of $15 \mathrm{nM}$ gInRA promoter DNA (Figure 2), implying that DNA is not required for GInR-GInK complex formation.

\section{GInK enhances DNA-binding activity of GInR in vitro}

The effect of GInK on the ability of GInR to bind $g \ln R A$ promoter DNA was determined using EMSA (Figure 3). Various concentrations of GInK were added to 50 nM GInR (protomer). In the presence of $150 \mathrm{nM}$ GInK (protomer), which corresponds to a 6 -fold excess over dimeric GInR
(25 nM), binding of GInR to DNA was increased 5-fold as estimated by band densitometry (Figure $3 A$, lane 5 ). This result suggests that two GInK trimers or, possibly, the hexameric form of GInK increases the affinity of the GInR dimer for DNA.

The EMSA analyses detected the formation of a stable ternary complex between GInR, GInK and DNA and confirmed the results of the pull-down experiments in the presence of DNA. Long-term EMSA indicated that the ternary complex exhibited a considerably lower mobility than the

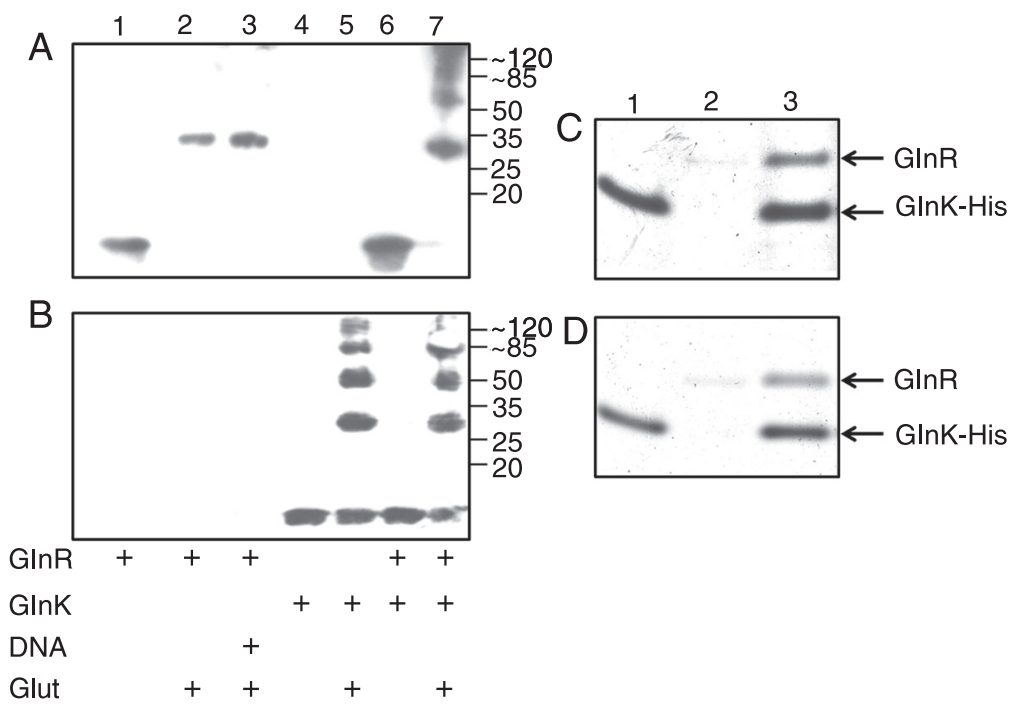

Figure 2. Formation of the GInR-GInK complex in vitro. $A$ and $B$, Western blots of $\mathrm{G} \operatorname{lnR}$ and GInK cross-linking experiments. Cross-linking reactions containing the indicated components were separated by $15 \%$ SDS-PAGE and evaluated by Western blot analysis with anti-GInR $(A)$ or anti-GInK $(B)$ antiserum. Native $G \ln R$, native $\mathrm{G} \operatorname{lnK}, g \ln R A$ promoter DNA, and glutaraldehyde (Glut) were used at concentrations of $2.5,2.5$, and $0.4 \mu \mathrm{M}$, and $0.1 \%(\mathrm{v} / \mathrm{v})$, respectively. $C$ and $D$, His-tag pull-down assay. Resin was loaded with $5 \mu \mathrm{M}$ GInK-(His) 6 (12.1 kDa; $C$ and $D$, lanes 1 and 3 ) and $2.5 \mu \mathrm{M} \mathrm{GInR} \mathrm{(14.3}$ $\mathrm{kDa} ; C$ and $D$, lanes 2 and 3). DNA fragments containing $g / n R A$ promoter DNA (15 $\mathrm{nM})$ were added to the reaction mixture $(D)$ Tricine-SDS $10 \%$ gel electrophoresis of proteins eluted from the resin. Arrows indicate the identified proteins.

Figure 3. The influence of $\mathrm{GlnK}$ on $\mathrm{GlnR}$ binding to DNA. A, Native GInR (50 nM promoter) was incubated with $0.3 \mathrm{nM}$ of a radiolabeled 311-bp gInRA promoter DNA fragment, and increasing quantities of native GlnK protomer. Lane $1=$ no GInR; lane 2 = GlnR; lanes 3-5 = GlnR and 25 nM GInK; GInR and 75 nM GInK, and GInR and 150 $\mathrm{nM}$ GInK, respectively. $B$, Native GlnR (50 nM) was incubated with $6 \mathrm{nM}$ of the $g I n R A$ promoter DNA fragment and $25 \mathrm{nM}$ native $\mathrm{GlnK}$, and electrophoresis was performed for twice the duration of the other gels described in this study. Lane $1=$ no GlnR; lane 2 = GlnR; lane $3=\mathrm{GlnR}$ and GInK. $C$, Increasing quantities of native GInR were incubated in the presence of $3 \mathrm{nM} g \ln R A$ promoter DNA fragments. Lane $1=$ no GlnR; lanes 2-7 = $10,25,50,10,250$, and $500 \mathrm{nM} \mathrm{GInR}$, respectively. $D$, Increasing quantities of native $\mathrm{GlnR}$ and native GlnK were incubated in the presence of 3 $\mathrm{nM}$ gInRA promoter DNA fragments. Lane $1=$ no proteins; lane 2 = $600 \mathrm{nM} \mathrm{GInK;} \mathrm{Lanes} \mathrm{3-8}=10$ nM GInR and 30 nM GInK; 20 nM GInR and 60 nM GlnK; 50 nM GlnR and 150 nM GlnK; 100 nM GInR and 300 nM GInK; 200 nM GInR and 600 $\mathrm{nM}$ GInK, and $500 \mathrm{nM}$ GlnR and $1.5 \mu \mathrm{M}$ GlnK, respectively. 
GInR-DNA complex (Figure 3B, lane 3).

The effect of GInK on the affinity of GInR binding to gInRA promoter DNA was also examined by EMSA(Figure $3 C$ and D). GInK did not bind DNA fragments under these conditions (Figure 3D, lane 2). In the presence of a 6-fold excess of GInK protomer relative to the GInR dimer, the $K_{0.5}$ was $13 \mathrm{nM}$ (Figure 3D). When only GInR was present in the reaction mixture, the $K_{0.5}$ was $50 \mathrm{nM}$ (Figures $1 \mathrm{~A}$ and $3 C)$. These results indicate that GInK increases GInR-DNA binding activity by a factor of approximately 4 .

\section{Discussion}

We report here the cloning, expression, and purification of the S. mutans GInR protein. Our results demonstrate that S. mutans $\mathrm{G} \ln R$ binds to gInRA promoter DNA, as described for $B$. subtilis $G \ln R(12)$, and that $S$. mutans $G \ln R$ binds the amtB-glnK promoter. These results agree with the in vivo results obtained by Chen et al. (8), which showed that S. mutans GInR regulates its own transcription and the transcription of the amtB-glnK operon.

The present study describes for the first time an interaction between S. mutans GInK and GInR in vitro (Figure 2). EMSA analyses identified stable GInR-GInK-DNA complexes (Figure 3B). In B. subtilis, GInK binds to the TnrA protein, which is functionally and structurally analogous to GInR (23). However, no studies have examined the modulation of TnrA or GInR activity by GInK.

Compared to GInR alone, S. mutans GInR bound to GInK has a 4-fold higher affinity for $g$ InRA promoter DNA (Figure $3 \mathrm{C}$ and $\mathrm{D}$ ), suggesting that GInK enhances GInR-mediated transcriptional repression of the gInRA promoter.

Interactions between GInK and various transcription factors have been described for the Gram-positive Corynebacterium glutamicum. In this microorganism, adenylylated GInK interacts with AmtR, a transcriptional repressor, leading to de-repression of genes involved in the control of

\section{References}

1. Loesche WJ. Role of Streptococcus mutans in human dental decay. Microbiol Rev 1986; 50: 353-380.

2. Banas JA. Virulence properties of Streptococcus mutans. Front Biosci 2004; 9: 1267-1277.

3. Tamura GS, Nittayajarn A, Schoentag DL. A glutamine transport gene, glnQ, is required for fibronectin adherence and virulence of group B streptococci. Infect Immun 2002; 70: 2877-2885.

4. Hendriksen WT, Kloosterman TG, Bootsma HJ, Estevao S, de Groot R, Kuipers OP, et al. Site-specific contributions of glutamine-dependent regulator GInR and GInR-regulated genes to virulence of Streptococcus pneumoniae. Infect Immun 2008; 76: 1230-1238.

5. van Schaik W, Chateau A, Dillies MA, Coppee JY, Sonenshein $A L$, Fouet $A$. The global regulator $\mathrm{Cod} Y$ regulates toxin nitrogen metabolism (31). In cyanobacteria, GInK regulates gene expression by binding to NtcA and PipX proteins. NtcA is a global transcriptional activator, and PipX binds to and enhances the activity of NtcA during nitrogen starvation. Under nitrogen excess, GInK interacts with PipX to impair NtcA activation (32-34).

Almost all PII-type proteins are trimeric; however, gel filtration chromatography results suggest that the GInK protein of $S$. mutans has the molecular weight of a hexamer in solution (27). Supporting this, an S. mutans GInK structure deposited in the Protein Data Bank (PDB ID: 3L7P) is described as a biological assembly of six domains (Fan X-X, Wang K-T, Su X-D; Protein Data Bank, 2011). Our results suggest that a 6-fold excess of GInK promoter increases the affinity of the GInR dimer for $g$ InRA operon promoter DNA. This implies that two trimers of GInK protein, or possibly its hexameric form, are responsible for the increase in GInR DNA-binding activity (Figure $3 A$ and D).

GInR-DNA binding was confirmed in vitro for the amtBglnK and $g$ InRA promoters. The in vitro formation of a stable complex between GInR and GInK is described here for the first time. Once bound to GInK, GInR exhibits a higher affinity for $g$ InRA promoter DNA. Information regarding nitrogen availability is likely to be transmitted to $G \ln R$ via GInK binding in $S$. mutans.

Future in vivo studies should permit the determination of the physiological conditions in which the GInR-GInK interaction occurs.

\section{Acknowledgments}

We thank Prof. Susan H. Fisher for advice regarding EMSA parameters, Prof. Dennis G. Cvitkovitch for providing the S. mutans UA159 strain, and Prof. Fábio de Oliveira Pedrosa, Instituto Nacional de Ciência e Tecnologia - Fixação de Nitrogênio, for access to the equipment. Research supported by CNPq (\#140152/2007-5). gene expression in Bacillus anthracis and is required for full virulence. Infect Immun 2009; 77: 4437-4445.

6. Gustafson J, Strassle A, Hachler H, Kayser FH, BergerBachi B. The femC locus of Staphylococcus aureus required for methicillin resistance includes the glutamine synthetase operon. J Bacteriol 1994; 176: 1460-1467.

7. Somerville GA, Proctor RA. At the crossroads of bacterial metabolism and virulence factor synthesis in Staphylococci. Microbiol Mol Biol Rev 2009; 73: 233-248.

8. Chen PM, Chen YY, Yu SL, Sher S, Lai CH, Chia JS. Role of $\mathrm{G} \operatorname{lnR}$ in acid-mediated repression of genes encoding proteins involved in glutamine and glutamate metabolism in Streptococcus mutans. Appl Environ Microbiol 2010; 76: 2478-2486

9. Merrick MJ, Edwards RA. Nitrogen control in bacteria. Mi- 
crobiol Rev 1995; 59: 604-622.

10. Arcondeguy $T$, Jack R, Merrick M. P(II) signal transduction proteins, pivotal players in microbial nitrogen control. Microbiol Mol Biol Rev 2001; 65: 80-105.

11. Amon J, Titgemeyer F, Burkovski A. Common patterns unique features: nitrogen metabolism and regulation in Gram-positive bacteria. FEMS Microbiol Rev 2010; 34: 588605.

12. Schreier HJ, Brown SW, Hirschi KD, Nomellini JF, Sonenshein AL. Regulation of Bacillus subtilis glutamine synthetase gene expression by the product of the glnR gene. $J$ Mol Biol 1989; 210: 51-63.

13. Wray LV Jr, Ferson AE, Rohrer K, Fisher SH. TnrA, a transcription factor required for global nitrogen regulation in Bacillus subtilis. Proc Natl Acad Sci U S A 1996; 93: 8841 8845.

14. Brown SW, Sonenshein AL. Autogenous regulation of the Bacillus subtilis glnRA operon. J Bacteriol 1996; 178: 24502454.

15. Wray LV Jr, Ferson AE, Fisher SH. Expression of the Bacillus subtilis ure $A B C$ operon is controlled by multiple regulatory factors including CodY, GInR, TnrA, and SpoOH. J Bacteriol 1997; 179: 5494-5501.

16. Zalieckas JM, Wray LV Jr, Fisher SH. Cross-regulation of the Bacillus subtilis glnRA and tnrA genes provides evidence for DNA binding site discrimination by GInR and TnrA. J Bacteriol 2006; 188: 2578-2585.

17. Wray LV Jr, Zalieckas JM, Ferson AE, Fisher SH. Mutational analysis of the TnrA-binding sites in the Bacillus subtilis nrgAB and gabP promoter regions. J Bacteriol 1998; 180: 2943-2949.

18. Brandenburg JL, Wray LV Jr, Beier L, Jarmer H, Saxild HH, Fisher SH. Roles of PucR, GInR, and TnrA in regulating expression of the Bacillus subtilis ure $\mathrm{P} 3$ promoter. J Bacteriol 2002; 184: 6060-6064.

19. Nakano MM, Hoffmann T, Zhu Y, Jahn D. Nitrogen and oxygen regulation of Bacillus subtilis nasDEF encoding NADHdependent nitrite reductase by TnrA and ResDE. J Bacteriol 1998; 180: 5344-5350.

20. Belitsky BR, Wray LV Jr, Fisher SH, Bohannon DE, Sonenshein AL. Role of TnrA in nitrogen source-dependent repression of Bacillus subtilis glutamate synthase gene expression. J Bacteriol 2000; 182: 5939-5947.

21. Fisher SH, Wray LV Jr. Novel trans-acting Bacillus subtilis gInA mutations that derepress glnRA expression. $J$ Bacteriol 2009; 191: 2485-2492.

22. Fisher SH, Wray LV Jr. Bacillus subtilis glutamine synthetase regulates its own synthesis by acting as a chaperone to stabilize GInR-DNA complexes. Proc Natl Acad Sci U S A 2008; 105: 1014-1019.

23. Heinrich A, Woyda K, Brauburger K, Meiss G, Detsch C, Stulke J, et al. Interaction of the membrane-bound GInKAmtB complex with the master regulator of nitrogen metabolism TnrA in Bacillus subtilis. J Biol Chem 2006; 281: 34909-34917.

24. Ajdic D, McShan WM, McLaughlin RE, Savic G, Chang J, Carson MB, et al. Genome sequence of Streptococcus mutans UA159, a cariogenic dental pathogen. Proc Natl Acad Sci U S A 2002; 99: 14434-14439.

25. Laemmli UK. Cleavage of structural proteins during the assembly of the head of bacteriophage T4. Nature 1970; 227 : 680-685.

26. Bradford MM. A rapid and sensitive method for the quantitation of microgram quantities of protein utilizing the principle of protein-dye binding. Anal Biochem 1976; 72: 248-254.

27. Portugal ME, Souza EM, Pedrosa FO, Benelli EM. Streptococcus mutans GInK protein: an unusual PII family member. Braz J Med Biol Res 2011; 44: 394-401.

28. Levitzki A. Ligand binding. In: Creighton TE (Editor), Protein function: a practical approach. 2nd ed. Oxford: IRL Press; 1997. p 119.

29. Sambrook J, Fritsch EF, Maniatis T. Molecular cloning: a laboratory manual. New York: Cold Spring Harbor Laboratory Press; 1989.

30. Neville DM Jr. Molecular weight determination of proteindodecyl sulfate complexes by gel electrophoresis in a discontinuous buffer system. J Biol Chem 1971; 246: 63286334.

31. Beckers G, Strosser J, Hildebrandt U, Kalinowski J, Farwick $\mathrm{M}$, Kramer R, et al. Regulation of AmtR-controlled gene expression in Corynebacterium glutamicum: mechanism and characterization of the AmtR regulon. Mol Microbiol 2005; 58: $580-595$

32. Espinosa J, Forchhammer K, Burillo S, Contreras A. Interaction network in cyanobacterial nitrogen regulation: PipX, a protein that interacts in a 2-oxoglutarate dependent manner with PII and NtcA. Mol Microbiol 2006; 61: 457-469.

33. Espinosa J, Forchhammer K, Contreras A. Role of the Synechococcus PCC 7942 nitrogen regulator protein PipX in NtcA-controlled processes. Microbiology 2007; 153: 711718.

34. Forchhammer K. P(II) signal transducers: novel functional and structural insights. Trends Microbiol 2008; 16: 65-72. 